\title{
Availability of Adequate Iodized Salt at Household Level and Associated Factors in Rural Communities in Laelay Maychew District, Northern Ethiopia: A Cross Sectional Study
}

\author{
Gidey $\mathrm{B}^{1}$, Alemu $\mathrm{K}^{2}$, Atnafu $\mathrm{A}^{3}$, Kifle $\mathrm{M}^{* 2}$, Tefera $\mathrm{Y}^{2}$ and Sharma $\mathrm{HR}^{4}$
}

${ }^{1}$ School of Public Health, Axum University, Ethiopia

${ }^{2}$ Department of Environmental and Occupational Health and Safety, Institute of Public Health, College of Medicine and Health Science, University of Gondar, Ethiopia

${ }^{3}$ Department of Nutrition, Institute of Public Health, College of Medicine and Health Science, University of Gondar, Ethiopia

${ }^{4}$ Institute of Environmental Studies, Kurukshetra University, Kurukshetra, Haryana, India

${ }^{*}$ Corresponding author: Kifle M, Department of Environmental and Occupational Health and Safety, Institute of Public Health, College of Medicine and Health Science, University of Gondar, Ethiopia, Tel.: +251913372878, E-mail: manay2000@gmail.com

Citation: Gidey B, Alemu K, Atnafu A, Kifle M, Tefera Y, et al. (2015) Availability of Adequate Iodized Salt at Household Level and Associated Factors in Rural Communities of Laelay Maychew District, Northern Ethiopia: A Cross Sectional Study. J Nutr Health Sci 2(1): 103. doi: 10.15744/2393-9060.1.403

Received Date: November 10, 2014 Accepted Date: February 03, 2015 Published Date: February 09, 2015

\begin{abstract}
Background: Universal salt iodization is cost-effective, safe and sustainable strategy to ensure adequate intake of iodine by all populations. Worldwide the proportion of people consuming iodized salt dramatically increased while, the coverage of universal salt iodization is still low in Ethiopia.

Objective: The aim of the study was to assess the availability of iodized salt and associated factors among households in rural communities of Laelay Maychew District.

Methods: Community based cross-sectional study was conducted using structured and pre-tested questionnaire via interview. Multistage sampling technique was used; in the first stage wards were selected using simple random sampling, and then households were selected using systematic random sampling technique. The collected data were entered, cleaned and analyzed using SPSS version 20 software. Variables having $\mathrm{p}<0.2$ in the bivariate logistic regressio were entered into multivariate logistic regression analysis and finally, variables having $\mathrm{p}<0.05$ were considered as significant associated.

Results: Out of the 610 households 600 female respondents were interviewed which gave $98.4 \%$. About $33 \%$ of the respondents were utilized adequately iodized salt and the main reasons given for not using iodized packed salt were lack of awareness about its benefits (44.2\%), being expensive (20\%) and difficulties to find (25.8\%). Few (2.7\%) respondents exposed their salt to sunlight, $92.3 \%$ of salt containers had a cover, $91.8 \%$ stored the salt in dry places and 51.7\% stored for more than two months after purchase. Around 59.7\%, of the respondents usually add salt late at the end of cooking, $40.3 \%$ add salt in the early beginning and in the middle of cooking. Mothers who attended formal education ( $\mathrm{AOR}=2.207,95 \% \mathrm{CI}$ : 1.27, 3.39), who had good knowledge about iodized salt and iodine deficiency disorders (AOR=2.11, 95\%CI: 1.37, 3.25) and households who stored for short-term salt at the household (AOR=1.61, 95\%CI: 1.10, 2.35) were more likely to have adequate iodized salt at household level.

Conclusion: Availability of adequate iodized salt was low, and attending formal education, having good knowledge about iodized salt and iodine deficiency disorders and short-term salt at the household were significantly associated with the availability of adequately iodized salt. So, dissemination of information and awareness about the importance of utilizing iodized salt at household level could be effective.

Keywords: Iodized salt; Household; Rural people; Ethiopia
\end{abstract}

\section{Background}

A deficiency of iodine leads to insufficient production of thyroid hormone, which have a wide range of negative consequences on various organs and muscle functions, particularly heart, liver, kidneys and most devastatingly in the developing brain [1-3]. Iodine deficiency is a major health problem throughout the world and the greatest cause of preventable brain damage in childhood, which is the primary motivation behind the current worldwide initiatives to eliminate iodine deficiency through the strategy of universal salt iodization (USI) [4]. The USI is a proven strategy to eliminate iodine deficiency and aims to make sure all edible salt iodized because, salt is an ideal vehicle for introducing iodine into people's diet and consumed by nearly every person, in roughly equal amounts, throughout the year [5]. Even though the World Health Organization (WHO) and the United Nations International Ch- 
ildren's Fund (UNICEF) had recommended USI as cost-effective, safe and sustainable strategy to ensure adequate intake of iodine by all populations, globally, around 2.2 billion people live in areas with iodine deficiency [6]. The world's school children urinary iodine data showed that iodine deficiency is still a public health problem in several countries and the iodine intake of $36.5 \%$ world's children is inadequate [7].

Worldwide the proportion of people consuming iodized salt dramatically increased, from less than $20 \%$ in the early 90 's to about $70 \%$ by 2000 . However, 38 million newborns in developing countries every year remain unprotected from the lifelong effect of brain damage associated with iodine deficiency disorders (IDD) [4,8]. According to the survey conducted in 2007 in Ethiopia about 6 million women in age category of 15- 49 years were affected by total goiter and, women living in highly goiter endemic areas were more likely to experience reproductive failure in the form of miscarriage and stillbirth than those living in less endemic regions [9].

Different studies in East Africa demonstrated a varied level of household consumption of adequate iodized salt in Uganda (96\%) , Ghana (75.6\%), South Sudan (72.9\%), and Somalia (6.7\%) [11-14]. According to the Ethiopian Demographic and Health Survey (EDHS) report of 2011, only $15.4 \%$ of the Ethiopian population use iodized salt and the percentage is higher in urban areas (23.2\%) than in rural areas (13.3\%). At the regional level, Benishangul-Gumuz (40\%) and Addis Ababa (30\%) had the highest proportions of households using iodized salt and Dire Dawa and Harari regions had the lowest (6\%) whereas, in Tigray region $22.3 \%$ of households were using iodized salt [15] however, as per WHO to eliminate IDD salt iodization needs to achieve 90\% [5].

Hence, Ethiopia set an objective to achieve the goal of "Virtual elimination of IDD by 2015" by means of USI [16]. Although, the rural Ethiopian communities had low levels of adequately iodized salt use, the availability of adequately iodized salt at the household level in the rural Laelay Maychew District and the factors affecting the availability wasn't well known. Therefore, the outcome of the present study will be important for planning of the availability of adequately iodized salt for household level and for the promotional activities to aware the public for use.

\section{Methods}

\section{Study design, period and Setting}

Community based cross-sectional study was conducted from March 10 to April 10, 2014 to assess the availability of adequately iodized salt and associated factors among households in rural communities. The study was carried out in four randomly selected rural wards of Laelay Maychew, District, which is located at $1004 \mathrm{~km}$ from the National capital of Addis Ababa and $248 \mathrm{~km}$ from Mekelle, which is the capital city of Tigray region. The district is divided into 16 wards and has a population of 86,312 in 16039 households. The health coverage of the district was $80 \%$, and there were four public health centers, 15 health posts with two health extension workers in each community health post to provide basic primary health care services [17].

\section{Sample size and Sampling Procedure}

The sample size of 610 households was determined using a single proportion formula by taking p(prevalence of adequately iodized salt $13.3 \%$ ) [18] taken from previous study, by considering the following assumptions: $\mathrm{Z} \mathrm{a} / 2=$ critical value at $95 \%$ confidence interval which is equal to 1.96 ( $\mathrm{z}$ value at alpha $=0.05), \mathrm{d}=$ margin of error $(0.04)$, design effect $(\mathrm{D})=2$, and then, adding $10 \%$ for non-response rate.

\section{Sampling Procedure}

Multi-stage sampling technique was used to select the study participants, at the first stage 4 wards were selected using simple random sampling from the total 16 wards in the district, and then the total sample size was allocated proportionally to each selected wards. In the second stage, households were selected using systematic random sampling techniques and every $8^{\text {th }}$ household was taken for the study after selection of the first household using a lottery method.

\section{Operational Definitions}

Availability of adequately iodized salt

Households' salt samples had $\geq 15 \mathrm{ppm}$ iodized salt when it was tested with rapid test kits [19].

Knowledge

Study participants who scored $\geq 50 \%$ regarding iodized salt and IDD knowledge questions were considered as having good knowledge, whereas, participants who scored below 50\% were considered as having poor knowledge [20].

\section{Storage of iodized salt}

Participants who store the purchased salt for more than two months were considered as having longer storage time, and those who stored for less than two months considered as having shorter storage time [21]. 


\section{Practice}

Respondents with any single practice that might result in the reduction of salt iodine content were labeled to have improper practice, and those without such practices were labeled to have proper practices [22].

\section{Data collection procedures, quality control and management}

The questionnaire was developed through literature review and was originally prepared in English and translated to Tigrigna (native language) and back to English in order to keep consistency. The questionnaire comprised of questions based on sociodemographic characteristics, knowledge, associated factors, availability and accessibility of iodized salt. The data was generated by using structured questionnaire via interview by trained eight female diploma nurses'. Four trained B. Sc. Nurses and principal investigator closely supervised the data collection and the collected data were checked for completeness, accuracy and clarity.

\section{Salt sample collection and testing}

Salt iodine testing is an important process indicator for monitoring progress towards USI. During the data collection sample of salt used for cooking was obtained to test the iodine content using MBI KITS international salt test kits. The newer MBI kits are inexpensive, require minimal training and provide quick results. The test kit contains a small white cup, 2 test solution ampules of $10 \mathrm{ml}$, a recheck solution ampule of $10 \mathrm{ml}$ and a color chart indicators for iodine content ranges of 0 ppm, less than $15 \mathrm{ppm}$ and more than $15 \mathrm{ppm}$. The salt samples were collected in cleaned and dried white injection bottle. The small cup in the kit was filled with salt, and made the cup surface flat. We add two drops of properly shake test solution on the surface of the salt by piercing the white ampoule with a pin and gently squeezing the ampule. The iodine content in the salt was determined after one minute by comparing the color developed on the salt with the color chart. If no color appears (after 1 minute), add up to 5 drops of the recheck solution in red ampule on a fresh salt sample spot and then add 2 drops of test solution on the same spot. Then, we compared the color with color chart and determined the iodine content [23]. Quality of iodine test kit was assured by observing its expiry dates and its proper use was assured through training of data collectors and supervisors.

\section{Data processing and analysis}

The collected data were cleaned and entered into EPI- INFO version 6. After exported, the data were analyzed using the Statistical Package for the Social Sciences (SPSS) version 20. Bivariate logistic regression was used to determine the association between independent and dependent variables and, variable with $\mathrm{p}<0.2$ were entered into multivariate logistic regression analysis. Variables having $\mathrm{p}<0.05$ were considered as significant and adjusted odds ratio (AOR) with $95 \%$ CI was used to interpret the result. The goodness of model fitness was tested using Hosmer and Lemeshow test at $\mathrm{p}>0.05$ and the result of the regression analysis provides an evidence for model adequacy well fit with the predictors $(\mathrm{P}=0.598)$. The Multico-linearity effect was checked using VIF $<10 /$ Tolerance tests $>0.10$. Furthermore, the analysis provides Nagelkerke's R-square $\left(r^{2}=0.324\right)$, to mean that the model explains $32.4 \%$ of the variation for the availability of adequately iodized salt in the households is explained by the selected explanatory variables.

\section{Ethical consideration}

Ethical clearance was obtained from the Institutional Review Board of Institute of Public Health, College of Medicine and Health Science, University of Gondar and, through formal letter from Laelay Maychew District Administration. After explaining the objectives of the study, written and verbal informed consent was obtained from each study participant. Name and other personal identifiers were excluded and data were locked with a password to ensure confidentiality. Health education on the importance of iodized salt utilization, where to get iodized salt, how to handle and use were provided to those who do not use iodized salt.

\section{Results}

\section{Socio-demographic characteristics}

Out of the 610 households 600 female respondents were interviewed which gave $98.4 \%$ response rate. The mean age of the respondents was $37.7 \pm 10.4$ years, ranging from 18-72 years. The majority (99.7\%) of the respondents were Orthodox Christian by religion, $99.7 \%$ belonged to Tigray ethnic group, $91.8 \%$ were married, $89.3 \%$ were housewife by occupation and $62.2 \%$ were unable to read and write (Table 1 ).

\section{Availability of adequately iodized salt at household level}

The iodine content in the salt samples collected from $33 \%$ of the households was adequate i.e. $\geq 15$ ppm. Around $72.7 \%$ of the respondents were using common salt (coarse salt without plastic package) out of which, $83.3 \%$ was inadequately iodized. Twenty seven percent of the households used iodized packed salt (with original salt packages), out of which $76.2 \%$ was adequately iodized (Figure 1). The main reasons for not using packed iodized salt were lack of awareness about the benefit of iodized salt (44.2\%), being expensive compared with common salt (20\%), difficulty to find iodized salt (25.8\%), being less salty (0.9\%), and (9.1\%) being not familiar to use. More than half of the iodized packed salt users got it from the supermarkets. However, only $2.9 \%$ of the households have been using iodized salt for the last 6 years and above. 


\begin{tabular}{|c|c|c|}
\hline Variables & Frequency & Percent \\
\hline \multicolumn{3}{|l|}{ Age (in year) } \\
\hline $18-29$ & 137 & 22.8 \\
\hline $30-44$ & 311 & 51.8 \\
\hline$\geq 45$ & 152 & 25.3 \\
\hline \multicolumn{3}{|l|}{ Religion } \\
\hline Orthodox Christian & 598 & 99.7 \\
\hline Muslim & 2 & 0.3 \\
\hline \multicolumn{3}{|l|}{ Ethnicity } \\
\hline Tigray & 598 & 99.7 \\
\hline Amhara & 2 & 0.3 \\
\hline \multicolumn{3}{|l|}{ Marital status } \\
\hline Married & 551 & 91.8 \\
\hline Single & 12 & 2.0 \\
\hline Divorced & 6 & 1.0 \\
\hline Widowed & 31 & 5.2 \\
\hline \multicolumn{3}{|l|}{ Educational status } \\
\hline Unable to read and write & 373 & 62.2 \\
\hline Able to read and write & 62 & 10.3 \\
\hline Primary (grade1-8) & 135 & 22.5 \\
\hline Secondary (grade9-12) and above & 30 & 5 \\
\hline \multicolumn{3}{|l|}{ Occupational status } \\
\hline Housewife & 535 & 89.3 \\
\hline Other * & 65 & 10.7 \\
\hline \multicolumn{3}{|l|}{ Household family size } \\
\hline$\leq 5$ & 336 & 56.0 \\
\hline$>5$ & 264 & 44.0 \\
\hline
\end{tabular}

farmers, government employees, students and daily laborers

Table 1: Socio - demographic characteristics of household female respondents rural communities of Laelay Maychew District

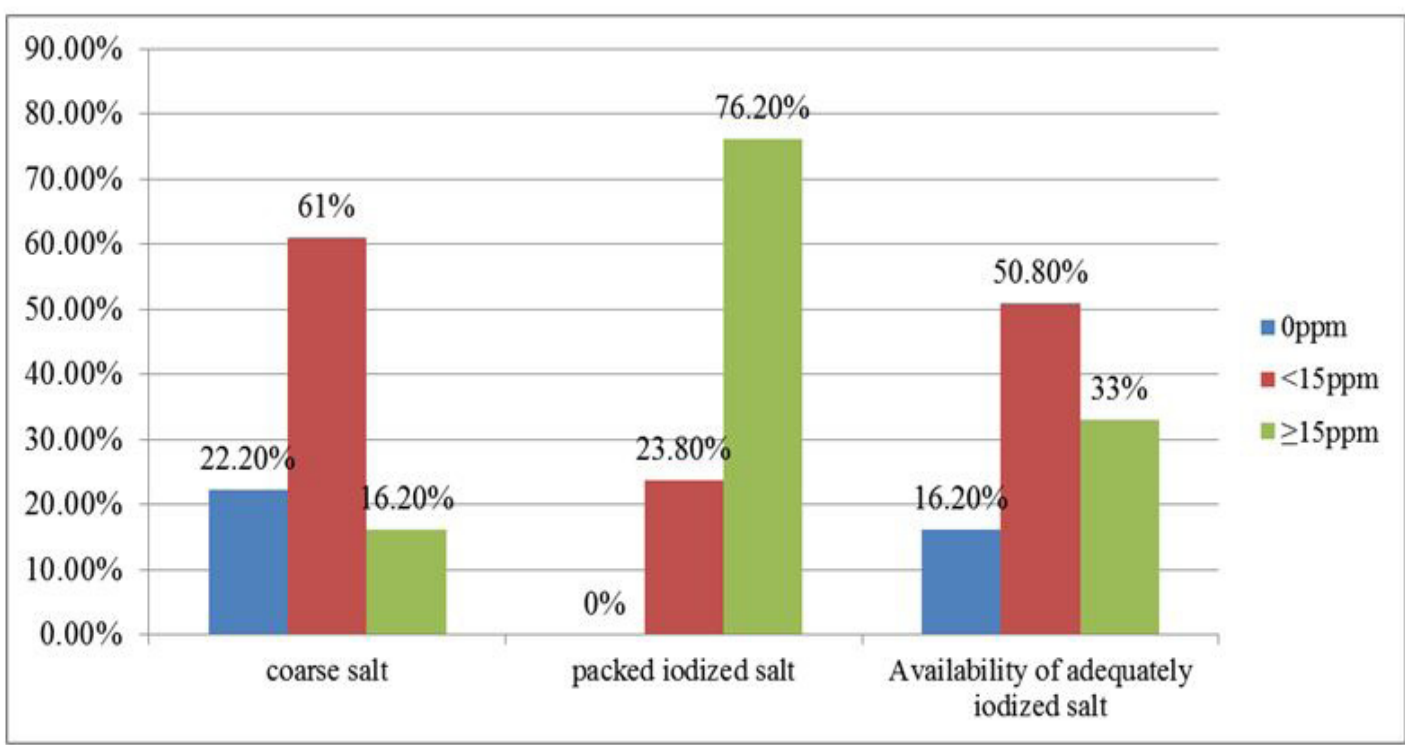

Figure 1: Availability of iodized salt and the type of salt used and its iodine content test result at household level in rural communities of Laelay Maychew District 
Only a few (2.7\%) respondents exposed the salt to sunlight, $92.3 \%$ of the salt containers had cover and, $91.8 \%$ the respondents store the salt in a dry place. Around $51.7 \%$ of respondents stored the salt for more than two months after purchase, out of which only $25.5 \%$ was adequately iodized. The remaining $48.3 \%$ stored the salt for less than two months after purchase out of which $41 \%$ were adequately iodized. Nearly $59.7 \%$ of the participants usually add salt late at the end of cooking and after cooking while, $40.3 \%$ add salt in the early beginning and in the middle of cooking (Table 2). Only 35.8\%, of the respondents had good knowledge of iodized salt and IDD, $77.2 \%$ heard about iodized salt, and $47.2 \%$ reported that iodized salt is important to prevent goiter. About $39.5 \%$ of respondents did not know the effects of iodine deficiency, $30.2 \%$ mentioned that every salt contains iodine and, $46.2 \%$ replied that the taste of iodized salt is different from that of common salt (Table 3). Regarding sources of information on iodized salt, $60.8 \%$ of the respondents obtained information from health care workers (Figure 2).

\begin{tabular}{|c|c|c|}
\hline Variables & Frequency & Percent \\
\hline \multicolumn{3}{|l|}{ Type of salt used } \\
\hline Iodized packed-salt & 164 & 27.3 \\
\hline Coarse salt (non-packed) & 436 & 72.7 \\
\hline \multicolumn{3}{|l|}{ Sunlight exposure to salt } \\
\hline Yes & 16 & 2.7 \\
\hline No & 584 & 97.3 \\
\hline \multicolumn{3}{|l|}{ Washing the salt before use } \\
\hline Yes & 19 & 3.2 \\
\hline No & 581 & 96.8 \\
\hline \multicolumn{3}{|l|}{ Salt storage place } \\
\hline Dry area & 551 & 91.8 \\
\hline Moist area & 16 & 2.7 \\
\hline Near to fire & 33 & 5.5 \\
\hline \multicolumn{3}{|l|}{ Salt container } \\
\hline With cover & 554 & 92.3 \\
\hline Without cover & 46 & 7.7 \\
\hline \multicolumn{3}{|l|}{ Duration of salt storage at household level } \\
\hline$\leq 2$ months & 290 & 48.3 \\
\hline$>2$ months & 310 & 51.7 \\
\hline \multicolumn{3}{|l|}{ Time salt is added during food cooking } \\
\hline Early and at the middle of cooking & 242 & 40.3 \\
\hline Late at the end of cooking and after cooking & 358 & 59.7 \\
\hline \multicolumn{3}{|l|}{ Distance traveled to get iodized salt } \\
\hline Less than 30 minutes & 49 & 29.9 \\
\hline Greater than 30 minutes & 115 & 70.1 \\
\hline
\end{tabular}

Table 2: Practice of respondents regarding the use of iodized salt in rural communities of Laelay Maychew District

\begin{tabular}{|c|c|c|}
\hline Variables & Frequency & Percent \\
\hline \multicolumn{3}{|l|}{ Knowledge } \\
\hline Good knowledge & 215 & 35.8 \\
\hline Poor knowledge & 385 & 64.2 \\
\hline \multicolumn{3}{|l|}{ Knew effects of iodine deficiency } \\
\hline Yes & 363 & 60.5 \\
\hline No & 237 & 39.5 \\
\hline \multicolumn{3}{|l|}{ Heard about iodized salt } \\
\hline Yes & 463 & 77.2 \\
\hline No & 137 & 22.8 \\
\hline \multicolumn{3}{|l|}{ Why intake of iodized salt is important? } \\
\hline To prevent from goiter ${ }^{\star}$ & 328 & 47.2 \\
\hline To keep healthy* & 197 & 28.3 \\
\hline To prevent iodine deficiency disorders ${ }^{*}$ & 124 & 17.8 \\
\hline To grow well* & 46 & 6.6 \\
\hline
\end{tabular}




\begin{tabular}{|c|c|c|}
\hline Variables & Frequency & Percent \\
\hline \multicolumn{3}{|c|}{ Every salt contains iodine } \\
\hline Yes & 181 & 30.2 \\
\hline No & 266 & 44.3 \\
\hline Do not know & 153 & 25.5 \\
\hline \multicolumn{3}{|c|}{ The taste of iodized salt is different from that of common salt } \\
\hline Yes & 277 & 46.2 \\
\hline No & 170 & 28.3 \\
\hline Do not know & 153 & 25.3 \\
\hline
\end{tabular}

Table 3: Knowledge of respondents regarding the importance of iodized salt in rural communities of Laelay Maychew District

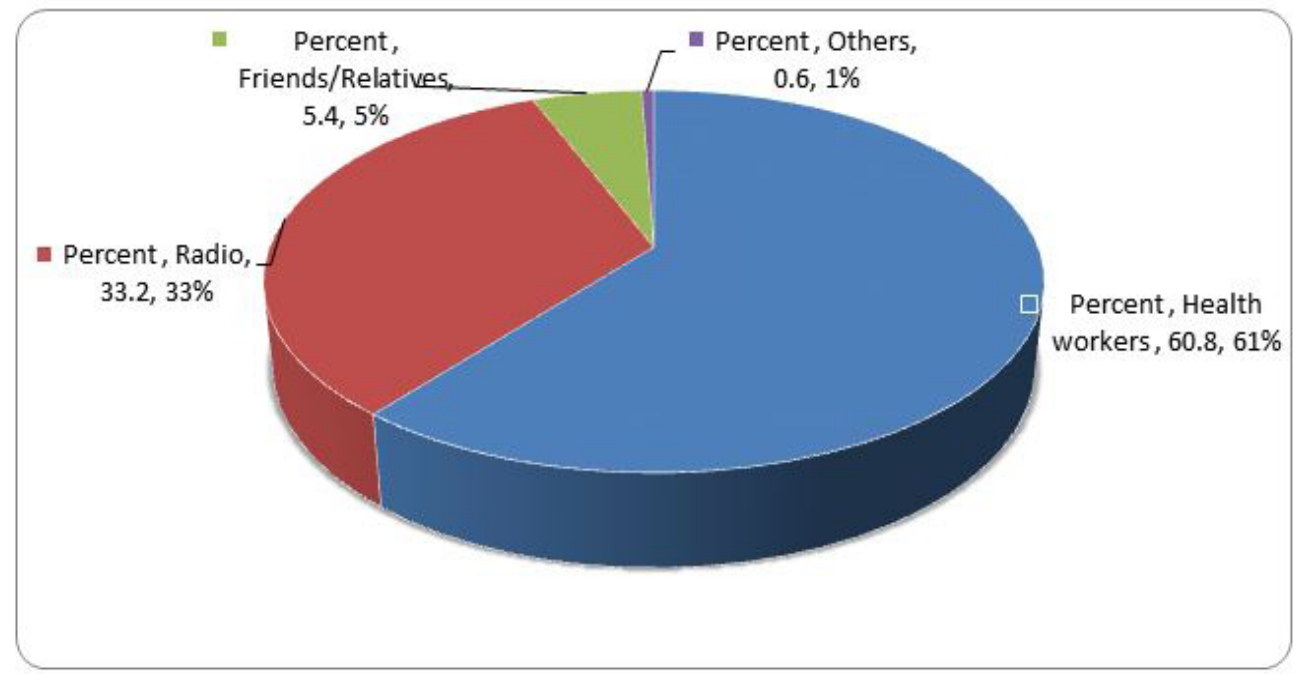

* Books and students

Figure 2: Source of information about iodized salt in rural communities of Laelay Maychew District

Factors associated with the availability of adequately iodized salt at household level

Being young age, having formal education, having good knowledge about iodized salt and IDD, shorter duration of storage, place of storage, having a radio and having a cover on the salt container were factors associated with the availability of adequately iodized salt in the bivariate logistic regression. However, in the multivariable logistic regression only, those attending formal education, having good knowledge about iodized salt and storing salt for less than two months at household level were associated with the availability of adequately iodized salt (Table 4).

\begin{tabular}{|c|c|c|c|c|}
\hline \multirow[t]{2}{*}{ Variables } & \multicolumn{2}{|c|}{$\begin{array}{c}\text { Availability of iodized salt at } \\
\text { household level }\end{array}$} & \multirow{2}{*}{$\begin{array}{l}\text { Crude OR } \\
(95 \% \mathrm{CI})\end{array}$} & \multirow{2}{*}{$\begin{array}{l}\text { Adjusted OR } \\
\quad(95 \% \mathrm{CI})\end{array}$} \\
\hline & $\geq 15 \mathrm{ppm}$ & $<15$ ppm & & \\
\hline \multicolumn{5}{|l|}{ Age (in years) } \\
\hline $18-29$ & 77 & 60 & $4.29[2.59-7.12]^{\star}$ & $1.80[0.99-3.23]$ \\
\hline $30-44$ & 86 & 225 & $1.28[0.81-2.01]$ & $0.83[0.50-1.36]$ \\
\hline$\geq 45$ & 35 & 117 & 1 & 1 \\
\hline \multicolumn{5}{|l|}{ Education } \\
\hline No formal education & 108 & 327 & 1 & 1 \\
\hline Formal education & 90 & 75 & $3.63[2.495-5.291]^{*}$ & $2.07[1.27-3.39]^{\star}$ \\
\hline \multicolumn{5}{|l|}{ Knowledge } \\
\hline Good knowledge & 111 & 104 & $3.66[2.55-5.23]^{\star}$ & $2.11[1.37-3.25]^{\star}$ \\
\hline Poor knowledge & 87 & 298 & 1 & 1 \\
\hline \multicolumn{5}{|l|}{ Salt container } \\
\hline With cover & 189 & 365 & $2.13[1.01-4.50]^{\star}$ & $1.23[0.55-2.78]$ \\
\hline No cover & 9 & 37 & 1 & 1 \\
\hline
\end{tabular}




\begin{tabular}{|c|c|c|c|c|}
\hline \multirow[t]{2}{*}{ Variables } & \multicolumn{2}{|c|}{$\begin{array}{c}\text { Availability of iodized salt at } \\
\text { household level }\end{array}$} & \multirow{2}{*}{$\begin{array}{l}\text { Crude OR } \\
(95 \% \mathrm{CI})\end{array}$} & \multirow{2}{*}{$\begin{array}{l}\text { Adjusted OR } \\
\quad(95 \% \mathrm{CI})\end{array}$} \\
\hline & $\geq 15 \mathrm{ppm}$ & $<15 p p m$ & & \\
\hline \multicolumn{5}{|l|}{ Place of Storage } \\
\hline Dry area & 189 & 362 & $2.32[1.10-4.88]^{*}$ & $1.76[0.79-3.93]$ \\
\hline Moist and Heat area & 9 & 40 & 1 & 1 \\
\hline \multicolumn{5}{|l|}{ Having radio } \\
\hline Yes & 100 & 150 & $1.71[1.22-2.42]^{*}$ & $1.17[0.76-1.80]$ \\
\hline No & 98 & 252 & 1 & 1 \\
\hline \multicolumn{5}{|c|}{ Duration of storage (in months) } \\
\hline$\leq 2$ months & 119 & 171 & $2.04[1.44-2.88]^{*}$ & $1.61[1.10-2.35]^{*}$ \\
\hline$>2$ months & 79 & 231 & 1 & \\
\hline
\end{tabular}

${ }^{*}$ P-value is significant at $\alpha<0.05$; OR- Odds Ratio; CI- Confidence Interval

Table 4: Variables associated with the availability of adequately iodized salt at household level in rural communities of Laelay Maychew District

\section{Discussion}

The present study result showed that $33 \%(95 \%, C I=29.2-36.7)$ of households have adequately iodized salt which was far lower than the WHO's recommendation according to which $>90 \%$ of the households should utilize adequately iodized salt to eliminate IDD [19]. However, the observed percentage was higher from research carried out in Gondar town (28.9\%) [20], EDHS 2011 report and the national coverage of iodized salt in rural households (13.3\%), Tigray region (22.3\%) [15], Somalia (7.7\%) [14] and that of Hawassa town, where none of the households were using adequately iodized salt [24]. This improved rate of availability of adequately iodized salt in the current study might be due to implementation of more effective strategies in the production and distribution of iodized salt at the retailer level to enhance universal salt iodization program by the Ethiopian Ministry of Health in the last few years. But, still the households use of iodized salt in this study was lower than studies conducted in South Africa (62.4\%), Uganda (96\%), Ghana (75.6\%) and South Sudan (72.9\%) [11-13,25], North 24 Parganas (72.9\%) [26] and Belgaum (50\%) [27] districts of India. Therefore, collaborated efforts should be strengthened further to access and utilize households adequately iodized salt in the study area.

The most frequently mentioned sources of information on iodized salt in this study were health workers (60.8\%) which is not consistent with that of Ghana and Gondar town studies, where radio and television were the main source of information, respectively $[12,20]$. This might be due to the current house to house educational strategy through health extension workers more deployed in the rural communities of Ethiopia. This study also showed that radio accounted as a source of information in $33.2 \%$. About $46.2 \%$ of the study participants replied that the taste of iodized salt is different from that of common salt which is in accordance with the study done in Ghana [12], where more than half of the study participants complained about the taste difference. The reason for this might be due to the psychological perception that the iodized salt is different from that of common salt. As evidenced, in a double-blind study conducted in Mongolia [28] respondents could not distinguish the taste difference between iodized and non-iodized salt. Hence, misconceptions among rural communities on the utilization of adequately iodized salt should be clarified through public media campaign and using the existing communication channels in the community.

Respondents attended formal education was significantly different in the availability of adequately iodized salt in the household. Similar studies from Singh City of Pakistan [29] and Basra city of Iraq [30] reported that household members with university education used iodized salt in the household than those with illiterate ones. This is due to the fact that education increases awareness and decision making of individuals. Therefore, education should be one of the main pathways of communicating information to alleviate IDD. In a similar trend, respondents having good knowledge about iodized salt and IDD were significantly different on the use of adequately iodized salt in the household. Findings from Bia District, Ghana [12] and Gondar town [20] indicated having good knowledge about iodized salt were positively associated with adequately iodized salt in the household. However, finding from Hawassa town [24] having knowledge about iodized salt was not significantly associated with the use of adequately iodized salt.

Duration of storage at household level was significantly associated with availability of adequately iodized salt which is consistent with study done in Gondar town [20]. This is due to the fact that iodine is easily volatile when exposed to different environmental conditions like heat, humidity, moisture and light during storage and distribution. Study from Canada [21] demonstrated that iodated salt losses $28-51 \%$ of its iodine after three months, 35-52\% after 6 months and up to $66 \%$ after 12 months. High humidity resulted in rapid loss of iodine from iodized salt ranging from $30-98 \%$ of the original iodine content. Likewise, an experimental study in London [18] showed that loss of iodine was $24-90 \%$ during 63 weeks storage when exposed to different environmental factors, whereas, the loss was only $5.6 \%$ after 13 months' of storage, where salt was stored in a glass jar. 


\section{Conclusion}

The availability of adequate iodized salt at household level was very low as compared to the WHO recommendation to prevent IDD. The availability of adequate iodized salt was found to be associated with formal education, having good knowledge about iodized salt and IDD and, short-term storage of salt at the household. Nutrition education program regarding proper storage, handling of iodized salt, duration of salt storage at home, and the importance of iodized salt needs to be implemented to increase community awareness. Educational campaigns through different communication media should target the less educated females who are the most responsible in utilizing adequately iodized salt in the family.

\section{Acknowledgment}

We would like to thank the University of Gondar for funding, to Laelay Maychew District Health Office, to all study participants, data collectors and supervisors without whom this study could not have been possible.

\section{References}

1. Wisnu C (2008) Determination of Iodine Species Content in Iodized Salt and Foodstuff During Cooking. Int Food Res J 15: 325-30.

2. Mannar MV, Dunn JT, Disorders (1995) Salt iodization for the elimination of iodine deficiency. International Council for Control of Iodine Deficiency Disorders The Netherlands.

3. Hetzel BS (2002) Eliminating iodine deficiency disorders: the role of the International Council in the global partnership. Bulletin World Hea Org 80: 410-2.

4. Bruno de Benoist MA, Ines Egli, Bahi Takkouche, Henrietta Allen (2004) Iodine status worldwide WHO Global Database on Iodine Deficiency. World Health Organization, Geneva.

5. World Health Organization (2007) Assessment of iodine deficiency disorders and monitoring their elimination: A Guide for programme managers. Switzerland , World Health Organization.

6. Fisch A, Pichard E, Prazuck T, Sebbag R, Torres G, et al. (1993)A new approach to combatting iodine deficiency in developing countries: the controlled release of iodine in water by a silicone elastomer. Am J Pub Health 83: 540- 5.

7. Andersson M, Takkouche B, Egli I, Allen HE, Benoist Bd (2005) Current global iodine status and progress over the last decade towards the elimination of iodine deficiency. Bull World Health Organ 83: 518-25.

8. UNICEF (2008) Sustainable elimination of iodine deficiency: Progress since the 1990 World Summit for Children: UNICEF.

9. Abuye C, Berhane Y (2007)The goitre rate, its association with reproductive failure, and the knowledge of iodine deficiency disorders (IDD) among women in Ethiopia: Cross-section community based study. BMC Public Health 7: 316.

10. Benoist BD, McLean E, Andersson M, Rogers L (2008) Iodine deficiency in 2007: global progress since 2003. Food and Nutrition Bulletin 29: 195-202.

11. Macro (2006) Opinion Research Corporation Macro International IOM. Uganda Demographic Health Survey 2006.

12. Buxton C, Baguune B (2012) Knowledge and practices of people in Bia District, Ghana, with regard to iodine deficiency disorders and intake of iodized salt Arch Public Health 70: 5.

13. Gaffar M, Mahfouz MS (2011) Peace impact on health: population access to iodized salt in south Sudan in post conflict period. Croatian Med J 52: 178-82.

14. Kassim IA, Moloney G, Busili A, Nur AY, Paron P, et al. (2014) Iodine Intake in Somalia Is Excessive and Associated with the Source of Household Drinking Water. J Nutri 144: 375-81.

15. Central Statistical Agency [Ethiopia] and ICF (2012) Ethiopia Demographic and Health Survey 2011. Addis Ababa, Ethiopia and Calverton, Maryland, USA: Central Statistical Agency and ICF International.

16. Federal Ministry of Health, National Guideline for Control and Prevention of Micronutrient Deficiencies, Federal Ministry of Health, Addis Ababa, Ethiopia. 17. Laely Mychew District (2013) Population census. Laelay Maychew: District Office.

18. Kelly FC (1953) Studies on the stability of iodine compounds in iodized salt. Bull World Health Organ 9: 217.

19. World Health Organization (WHO)/United Nations Children's Fund/International Council for Control of Iodine Disorders (2011) Assessment of Iodine Deficiency Disorders and Monitoring their Elimination. A Guide of Programme Managers. WHO/NHD/01.1. Geneva: WHO, 1-107.

20. Gebremariam HG, Yesuf ME, Koye DN (2013) Availability of Adequately Iodized Salt at Household Level and Associated Factors in Gondar Town, Northwest Ethiopia. ISRN Public Health 2013.

21. Diosady L, Alberti J, Mannar V, Stone T (1997) Stability of iodine in iodized salt used for correction of iodine-deficiency disorders. Food and Nutrition Bulletin 18: 388-96.

22. Takele L, Belachew T, Bekele T (2004) Iodine concentration in salt at household and retail shop levels in Shebe town, south west Ethiopia. East Afr Med J 80: 532-9.

23. Diosady L, Mannar V (2000) Development of rapid test kits for monitoring salt iodization. In: 8th World symposium, conference 2000: $965-70$.

24. Girma M, Loha E, Bogale A, Teyikie N, Abuye C, et al. (2012) Iodine deficiency in primary school children and knowledge of iodine deficiency and iodized salt among caretakers in Hawassa Town: Southern Ethiopia. Ethiopian J Health Devel 26: 30-5.

25. Jooste PL, Weight MJ, Lombard CJ (2001) Iodine concentration in household salt in South Africa. Bulletin of the World Health Organ 79: 534-40.

26. Sen TK, Das DK, Biswas AB, Chakrabarty I, Mukhopadhyay S, et al. (2010) Limited access to iodized salt among the poor and disadvantaged in North 24 Parganas district of West Bengal, India. J Health Popul Nutri 28: 369.

27. Kamath R, Bhat V, Rao R, Das A, KS G, et al. (2009) Prevalence of goiter in rural area of Belgaum district, Karnataka. Indian Journal of Community Medicine 34: 48 . 
28. Yamada C, Oyunchimeg D, Igari T, Buttumur D, Oyunbileg M, et al. (1998) Knowledge, attitudes, and practices of people in Ulaanbaatar, Mongolia, with regard to iodine-deficiency disorders and iodized salt. Food and Nutrition Bulletin 19: 353-8.

29. Imdad S, Shoukat MS, Khalid M (2008) Appraisal of the knowledge and practices about iodized salt amongst housewives in Toba Tek Singh City and the impact of socioeconomic factors on such knowledge and practices. Change 48: 79.

30. Ebrahim S, Muhammed N (2012) Consumption of iodized salt among households of Basra city, southern Iraq. Eastern Mediterranean Health Journal 18: 980.

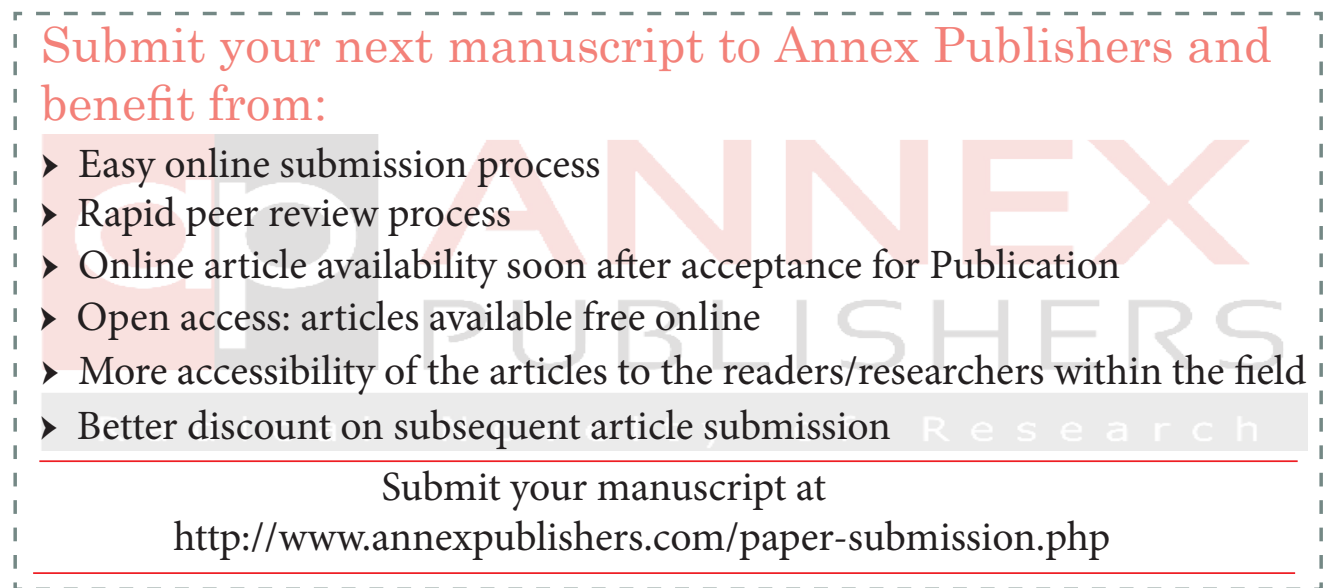

